\title{
A side effect of a university boom: rising incidence of overeducation among tertiary educated workers in Poland ${ }^{1}$
}

\author{
Jan Baran ${ }^{2}$
}

\begin{abstract}
This paper analyses changes in overeducation incidence in Poland in 2006-2014. It finds that a rise in number of tertiary educated workers outpaced an increase in number of jobs requiring tertiary education, which resulted in a substantial growth of overeducation incidence. The overeducation increase was driven mainly by mild overeducation rather than severe overeducation. Overeducated workers are usually young with little job experience. Women are found at lower risk of severe overeducation compared to men, but relatively more at risk of mild overeducation. A low risk of overeducation is associated with having studied technical and health programmes.
\end{abstract}

Keywords: overeducation, education mismatch, tertiary education.

JEL codes: I21, J21, J24.

\section{Introduction}

Poland experienced a substantial increase in number of tertiary educated workers. Between 1992-2014 the share of tertiary educated workers rose from $10.0 \%$ to $32.5 \%$. The change was even more pronounced for workers aged 25-34: from $9.8 \%$ in 1992 to $47.2 \%$ in 2014 . This immense expansion of tertiary education raises question whether it was accommodated by the labour market. There is a lot of anecdotal evidence suggesting that graduates increasingly take up jobs that do not require tertiary education. Though, the scientific evidence remains scarce in this matter. This article aims at filling this gap.

In the article we report incidence of overeducation among tertiary educated workers in Poland in 2006-2014. To identify overeducated workers we use rather rare approach based on employers' declarations what education level is

\footnotetext{
${ }^{1}$ Article received 30 August 2017, accepted 30 March 2018.

${ }^{2}$ University of Warsaw, Faculty of Economic Sciences, Długa Street 44/50, 00-241 Warsaw, Poland, jan.baran@wne.uw.edu.pl.
} 
required to perform jobs. This information is obtained from Balance of Human Capital (BKL) survey. To our knowledge it is the first time that BKL data are used in the analysis of overeducation. Moreover, characteristics of overeducated individuals are identified and discussed.

The structure of the paper is as it follows. Section 1 briefly reviews the literature on overeducation. Section 2 discusses methodology and data. Section 3 presents education requirements assigned to occupations. Section 4 reports changes in incidence of overeducation in working population in Poland. Section 5 reports results of an econometric model identifying characteristics of overeducated versus properly-matched tertiary educated workers. Finally, the last section summarises main findings of the analysis and builds conclusions for public policy.

\section{Literature review}

The overeducation has been attracting researchers' attention since 1976 starting with publication by Freeman (1976) who presented the evidence for the US that rising number of university graduates was followed by deterioration of tertiary education wage premium. Since then, analysis of overeducation has evolved into a separate branch of economic research that aims at answering questions about extent of overeducation, wage returns to overeducation and the persistence of overeducation. McGuinness (2006), Quintini (2011), Leuven and Oosterbeek (2011) provide excellent literature reviews in this matter. Although overeducation is a well-established notion in the economic literature, studies directly addressing overeducation in Poland are still scarce.

Methods to identify overeducation constitute a distinct issue in the literature on overeducation. They are usually grouped into four approaches: direct subjective approach, indirect subjective approach, job analysis approach and realised matches approach. The direct subjective method is based on individuals' selfassessment whether they think they are mismatched in respect of their education level. In the indirect subjective method individuals are asked about the education level that is needed in a given occupation and then this information is compared with education actually possessed by workers. In the job analysis approach occupations are assigned with educational levels based on experts' assessments. Finally, according to the realised matches approach, individuals are overeducated if their educational level is above modal / mean educational level for workers in their occupation. However, this listing is not exclusive. For instance, approaches proposed by Chevalier (2003), who combines objective and subjective information to identify what he calls 'apparent overeducation', or Gottschalk and Hansen (2003), who use combined information on share of college graduates within occupations and college wage premia, fail to suit well in this four-approach taxonomy. 
Choice of approach might affect results. Groot and Maassen van den Brink (2000) and Verhaest and Omey (2006) show that the realised matches approach gives significantly lower estimates of incidence of overeducation compared to other approaches. Even if numbers of overeducated individuals are similar, approaches might very differently indicate who is overeducated. Verhaest and Omey (2006) report that correlation between different approaches varies from $4 \%$ to $72 \%$.

Each overeducation identification method faces either conceptual or practical limitations. Approaches based on subjective assessments are vulnerable to a bias resulting from workers' misperception (Kruger \& Dunning, 1999). The realised matches method is associated with a severe endogeneity problem. A rapid increase in graduates in a non-graduate occupation might make this occupation turn into a graduate occupation. Hence it would imply lowering overeducation incidence instead of, what we would expect, increasing overeducation rates. The job analysis method, although apparently offering the least of conceptual limitations, requires specialist-made education requirement assessments. Such studies are rather scarce.

In the literature on correlates of overeducation, there is well-established relationship between workers' young age or little job experience and higher risk of overeducation (e.g., Leuven \& Oosterbeek, 2011; McGuinness, 2006; Sloane, Battu, \& Seaman, 1999; Sicherman, 1991; Quintini, 2011). Another well documented finding refers to immigrants who are often found to have higher risk of overeducation than natives (Aleksynska \& Tritah, 2013; Quintini, 2011). Studies show also that overeducation risk is associated with the size of labour market and workers at larger local labour markets experience lower risk of overeducation (Büchel \& van Ham, 2003; Jauhiainen, 2011). Similar intuition stands behind suggestion that women should be more likely to be overeducated as they tend to operate on more spatially restricted labour market compared to men (Quintini, 2011). However, the empirical evidence is mixed. The metaanalysis provided by Groot and Maassen van den Brink (2000) shows no link between gender of workers and overeducation.

Dynamics of overeducation is well-analysed from individuals' perspective. A debate on whether overeducation is transitory or long-lasting phenomenon builds on a paper by Sicherman and Galor (1990) which provides a theoretical model suggesting that overeducation is transitory state at the beginning of worker's job career. A large body of subsequent empirical research gives mixed results. There are numerous papers proving implications of Sicherman-Galor model (Dekker, De Grip, \& Heijke, 2002; Frei \& Sousa-Poza, 2012; McGuinness \& Wooden, 2009; Robst, 1995; Sicherman, 1991; Wasmer, Fredriksson, Lamo, Messina, \& Peri, 2007) as well as opposing them (Dolton \& Vignoles, 2000; Frenette, 2004; Lindley \& McIntosh, 2010; Mavromaras \& McGuinness, 2012; Rubb, 2003). 
However, few studies look at dynamics of overeducation from macroeconomic perspective. Based on meta-analysis of previous research, Groot and Maassen van den Brink (2000) find no evidence of changing incidence of overeducation over the 1970s, 1980s and 1990s. More recently, in the document prepared for the European Commision, Pouliakas (2013) reports that the incidence of overeducation in the European Union was stable over 2001-2009. However this finding results from 'credentialism', i.e. changing education requirements across occupations in response to an increasing number of tertiary educated workers. Keeping education requirements fixed would result in an increase in extent of overeducation. McGuinness, Bergin and Whelan (2015) report rising incidence of overeducation in most of European economies, including Poland.

There are a few studies focusing exclusively on a phenomenon of overeducation in Poland. Kucel and Vilalta-Bufi (2012) based on data from HEGESCO study that covered tertiary graduates. The advantage of their study is that they analyse three types of mismatch: vertical education mismatch (referring to levels of education), horizontal education mismatch (referring to fields of education), and skill mismatch. They solely base on the subjective approach. They find, when referring to vertical mismatch, that overeducation is negatively associated with being a woman, possessing executive skills, working in big companies, having a social sciences degree (compared to an engineering degree as a baseline), and having studied prestigious study programmes. Since the study covers individuals of one graduation cohort interviewed at the same moment of time, Kucel and Vilalta-Bufi cannot address dynamic aspects of overeducation.

Kiersztyn $(2011,2013)$ uses data from POLPAN study covering years $1988-$ -2008. The advantage of POLPAN is that it is a panel study that is conducted every five years. Kiersztyn (2011) reports descriptive results, whilst Kiersztyn (2013) presents results of an econometric analysis of determinants of overeducation. According to Kiersztyn (2011) incidence of overeducation rose in the analysed period of time. She finds that overeducation incidence among workers was $7.5 \%$ in 1988 whilst $19.1 \%$ in 2008. Subjective overeducation is found higher among young workers, aged $21-25$, than those aged 26 or more $(30 \%$ and $18 \%$ respectively). Similar numbers are reported for an objective measure of overeducation. Moreover, she demonstrates that overeducation in Poland is a persistent phenomenon. About 50\%-68\% respondents (depending on panel wave) who were overeducated remain overeducated after 5 years' time.

Kiersztyn (2013) confirms persistence of overeducation using econometric methods. Overeducated workers are found about four times more likely to be again in overeducation after five years compared to initially not overeducated workers. What is more, Kiersztyn shows that younger cohorts experience higher risk of persistent overeducation compared to older cohorts. This finding suggests that more recent cohorts struggle more to leave early-career overeducation than older cohorts did. 


\section{Methodology and data}

This section discusses the methodology and data used in the study. The outline of methodology of empirical analysis is as it follows. In the first step education requirements are assigned to occupations. In the second step required education is compared with workers' actual education level to identify overeducated workers and the extent of overeducation in the workforce is measured. In the final step we investigate characteristics associated with overeducation using logistic regression models.

Education requirements are assigned to occupations using employers' declarations on which education level is required from job candidates for current vacancies. For each occupation, defined at the 2-digit level of ISCO classification, we obtain frequency of surveyed employers responding that tertiary education is required. Having scores of tertiary education requirements across occupations, we assign occupations with low scores to the non-university jobs category, and occupations with high scores to the university jobs category.

Since a high share is a vague term, we need to choose a threshold value separating low and high scores. Data give no hint what the threshold value for a university job should be. Hence, we apply different threshold values: 70\%, $50 \%, 40 \%$, and $30 \%$. For instance, if the 70 -percent threshold is taken, only jobs with at least $70 \%$ of employers responding that tertiary education is needed are assigned to the university jobs category, the rest is considered non-university jobs. High and low thresholds identify different kind of overeducation. For low thresholds, $40 \%$ and $30 \%$, we detect severe overeducation, i.e. tertiary educated individuals who work in occupations that rarely require tertiary education. For high thresholds, the overeducation encompasses mild and severe overeducation. Furthermore, use of different thresholds works as a robustness check for our results.

Once each occupation is assigned to either university or non-university job category, we compare it with workers' actual education level. From the comparison we obtain four match-mismatch categories. There are two match categories: tertiary educated workers who work in jobs requiring tertiary education, and not tertiary educated workers who work in jobs not requiring tertiary education, and two mismatch categories: overeducated individuals, i.e. tertiary educated workers who work in jobs not requiring tertiary education, and undereducated individuals, i.e. workers without tertiary education who work in jobs requiring tertiary education. Having workers assigned to four categories, we report changes in incidence of overeducation over time.

In the econometric part we analyse characteristics associated with overeducation using logistic regression. For econometric analysis, we limit our sample to tertiary educated workers. The dependent variable is a dummy variable that takes value 1 for overeducated workers and value 0 for properly matched tertiary educated workers. The analysis is conducted for each threshold value. 
Explanatory variables include characteristics of worker and work as well as year and cohort dummies.

Worker's characteristics are: age, gender, whether the person is foreign born, whether the person is disabled, whether there is a child aged 3 or less in worker's household, whether there is other worker in worker's household, field of study, degree of urbanization of place of living, and voivodship. Variables related to work and workplace characteristics are: individual's tenure in the current workplace, whether the individual works part-time, sector of economic activity according to the NACE classification, size of firm, whether the firm is private or public owned. We include year and cohort dummies to verify if there is a rising risk of overeducation among tertiary educated workers. For each threshold value we present three estimations: basic model, full model, and full model with cohort dummies instead of age.

Data are taken from two sources: the Balance of Human Capital survey (Bilans Kapitału Ludzkiego, BKL) and the Polish Labour Force Survey (Badanie Aktywności Ekonomicznej Ludności (LFS) (Główny Urząd Statystyczny, 2015). BKL data are used for assigning education requirements to occupations. The BKL survey consists of several modules, one of them is a study on employers. In this module, employers are asked, inter alia, which level of education is required for candidates for recently vacating positions. Although the employers' answers are more detailed, education levels are aggregated into two: tertiary education and non-tertiary education. The BKL survey has been conducted each year since 2010. We use data from five editions of the survey and we pool them into one sample. For our best knowledge it is the first time that the BKL survey is used for identification of overeducation. For analysis of overeducation changes and characteristics of overeducation we use microdata from the Labour Force Survey for Poland for 2006-2014.

Three reservations about the analysis should be made. Firstly, there is apparent time discrepancy between LFS and BKL data we use. Education requirements are calculated on data for 2010-2014, whilst Labour Force Survey data cover 2006-2014. As education requirements might change over time, time discrepancy of the two datasets might cause some bias in identification of overeducation. However, we expect that the bias due to not allowing for changing education requirements is rather small as the analysed period of time is relatively short.

Secondly, there is the problem of changing occupation classification used in the Labour Force Survey. The problem is overcome with using correspondence tables, but perfect correspondence is not achieved. It results in a break in series for overeducation numbers between 2010 and 2011. However, the break is apparently small for total working population (see Table 1) and it tends to downsize overeducation incidence. Moreover, the steady increase in overeducation incidence is shown for both subperiods: before classification change, 2006-2010, and after the change, 2011-2014. It means that occupation classification change does not affect our findings. 
Thirdly, aggregating education requirements into two education levels might be perceived as too simplistic, but we do it for some reasons. It assures homogeneity of overeducation, i.e. when overeducation is identified it is always a tertiary educated worker with unmatched job, so we do not mix it with situation that a secondary educated individual works in a job which requires only primary education. Then, the two education level split suits better in the context of tertiary education boom. Moreover, the vast majority of workers in Poland have either secondary or tertiary education, whilst primary-education workers constitute a small share of the workforce (less than 6\% of workers in 2014).

\section{Identification of education requirement}

In this section education requirements across occupations are reported. The results of responses whether tertiary education is required are presented in Figure 1. As already mentioned, we obtain frequency of employers' responses that tertiary education is required from the BKL survey. Altogether there are 14,586 observations in the BKL sample, but the number of observations per occupation is unevenly distributed. For some 2-digit ISCO codes the number of observations is over one thousand, but there are occupations for which the number of observations is less than 100 or even less than 20 . These differences come from the fact that the number of observations reflects number of recent vacancies. Eight occupations with the lowest numbers of observations are assigned arbitrary to either university or non-university category.

The highest frequency of declared tertiary education requirement is found in professional and managerial jobs, belonging to major groups 1 and 2 of ISCO classification. Teaching and health professionals are at the top of ranking with scores of $97 \%$ and $91 \%$ respectively. Occupations that are least frequently claimed to require tertiary education belong to the following ISCO major groups: 5 service and sales workers, 7 craft and related trade workers, and 9 elementary occupations.

For the 70-percent threshold there are nine university jobs: all but one codes in managers and professionals ISCO sub-major groups (the exception is 14 hospitality, retail and other services managers). For the 50-percent threshold there are four more university jobs. Now, university jobs consist of all occupations of 1 and 2 major groups as well as 32 health associate professionals, 35 information and communications technicians and 41 general and keyboard clerks. For the 40-percent threshold we add further three occupations of 3 technicians and associate professionals major group. For the lowest threshold value, which is $30 \%$, there are 18 occupations assigned to university jobs out of 43 in the ISCO classification. The additional two are: 42 customer services clerks and 44 other clerical support workers. 


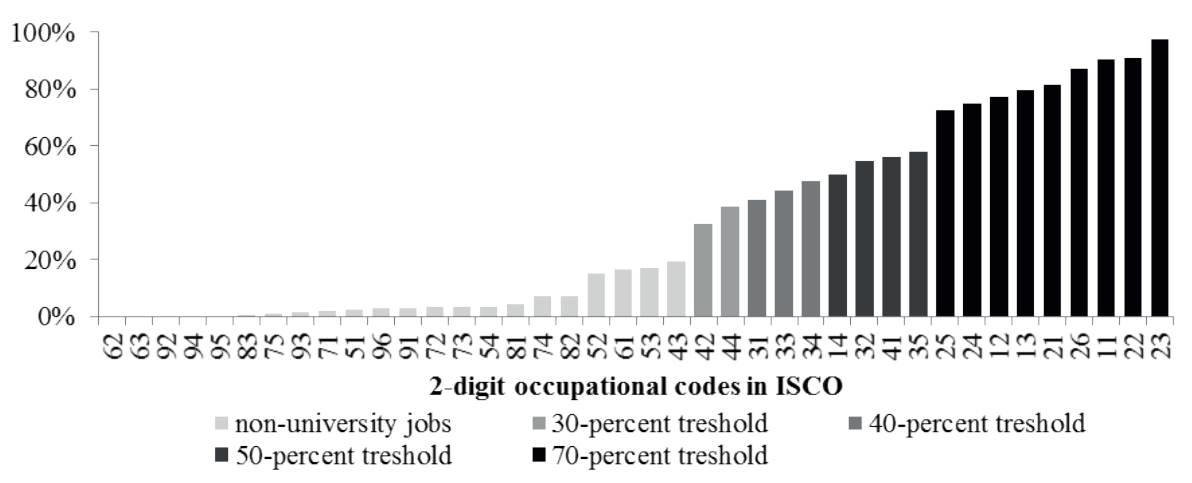

Figure 1. The share of employers' responses that tertiary education is required

Interestingly, tertiary education requirements claimed by employers are well correlated with ordering of occupations in the ISCO classification. Occupations in ISCO major groups 1 and 2 have requirements exceeding $70 \%$ of employers' positive responses that tertiary education is needed. Occupations in major groups 3 technicians and associate professionals, and 4 clerical support workers are found with $30 \%-50 \%$ of positive responses. Occupations in ISCO major groups 5-9 are reported with very low or none tertiary education requirement. However, there are some outlying occupations. 14 hospitality, retail and other services managers, with a 50\% tertiary requirement score, is much below scores for other managerial occupations. 43 numerical and material recording clerks, with a 19\% tertiary requirement score, lags behind scores for other clerical support workers. Strong correlation between the ISCO classification and actual education requirements is an important finding from the methodological perspective. It suggests that they both can be used interchangeably to identify overeducation with presumably similar implications. ${ }^{3}$ What is more, tertiary education requirements from employers' declarations are also strongly correlated with actual share of tertiary educated workers in occupations. The correlation between them is 0.95 .

\section{Changing incidence of overeducation}

In the previous section we discussed mapping of university and non-university jobs. Now we present the application of this mapping to Polish Labour Force Survey data in order to find how many workers with a university degree are overeducated. According to LFS data, in Poland there were 3,260 thousand workers with tertiary education in 2006 and 5,150 thousand in 2014. It means

\footnotetext{
${ }^{3}$ In fact, the ISCO classification was designed in such a way that ordering of occupations reflects reversely required skill levels.
} 
that number of tertiary educated workers expanded by 1,890 thousand in just eight years. As a result, the share of people with university diploma in total employment rose from $22.3 \%$ in 2006 to $32.5 \%$ in 2014 .

At the same time, the number of university jobs rose as well. The change depends on chosen threshold value used to identify university jobs. For 70-percent, the number of university jobs was 2,980 thousand in 2006 and 3,860 thousand in 2014. For 50-percent, it was 3,650 thousand in 2006 and 4,620 thousand in 2014 . For 40 -percent, we get 4,880 thousand and 6,240 thousand, respectively. Numbers for the 30-percent threshold value are respectively 5,090 and 6,520. Hence, university jobs expanded by between 880 thousand and 1,430 thousand. In each case the increase in number of university jobs was smaller than expansion of tertiary education among workers.

Consequently, the number of overeducated workers steadily increased. Table 1 in the appendix reports structure of working population broken into four categories: matched non-graduates, undereducated, overeducated and matched graduates. Data show a substantial increase in share of overeducated workers. Rising overeducation incidence prevails irrespectively of a threshold value used to define university jobs. For the 70-percent threshold, the share of overeducated workers in total employment rose from $6.7 \%$ in 2006 to $11.9 \%$ in 2014. For the 50-percent threshold, the change was from $5.5 \%$ to $9.8 \%$, respectively. For 40 -percent it was $3.3 \%$ and $5.4 \%$, respectively. Finally for the 30 -percent threshold, we report the change in the share of overeducated workers from $3.1 \%$ in 2006 to $4.8 \%$ in 2014. In other words, the share of overeducated individuals in working population almost doubled in eight years, especially for higher threshold definitions of university jobs.

Because of immense expansion of tertiary education, number of overeducated workers could significantly increase even with constant risk of being overeducated among tertiary educated workers. This is not the case. If we limit our analysis to tertiary educated workers only, the incidence of overeducation is also rising. For the 70 -percent threshold, the share of overeducated individuals in tertiary educated workers rose from $30.0 \%$ in 2006 to $36.7 \%$ in 2014. For the 50-percent threshold, the change is from $24.7 \%$ in 2006 to $30.3 \%$ in 2014. For the 40-percent and the 30-percent threshold, changes are much smaller: from $14.9 \%$ to $16.5 \%$ in the case of the former, and from $13.9 \%$ to $14.7 \%$ in the case of the latter. Hence, rising number of overeducated workers is driven by two factors: expansion of tertiary education and increasing risk of being overeducated among tertiary educated workers.

Larger expansion of overeducation is observed in case of higher thresholds than lower ones. It suggests that mild overeducation is rising much faster than severe overeducation. This observation is consistent with the finding that occupations that have experienced the greatest increase in a share of tertiary educated workers are those from the middle of tertiary education requirement distribution according to employers' responses. There is only little increase in 


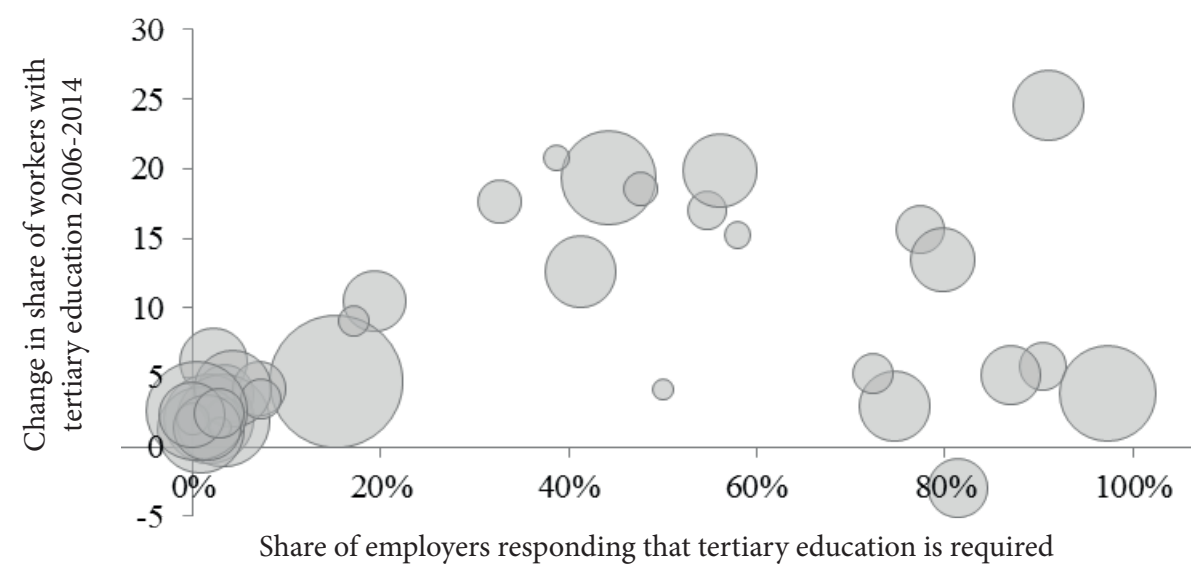

Figure 2. The change in share of tertiary educated workers in 2006-2014 (LFS) versus the share of employers responding that tertiary education is required

(BKL, 2010-2014)

Note: The size of the bubble represents number of workers in a given occupation in 2006.

the share of tertiary educated workers in jobs of the bottom of education requirement distribution (see Figure 2).

\section{Econometric analysis}

In this section we verify econometrically findings of rising incidence of overeducation presented in the previous section as well as we identify factors associated with being overeducated among tertiary educated workers. The results are presented in Table 2 in the appendix. Altogether there are twelve estimations reported. Values presented in the table are odds ratios.

Estimation results show that age is negatively associated with overeducation. This finding holds for basic and full model specifications. One additional year of age decreases probability of being in overeducation by $2.6-4.0 \%$. We identify also a statistically significant effect of tenure. One additional year of tenure in a current workplace decreases probability of being in overeducation by $1.3-2.7 \%$. Both results mean that overeducated individuals are usually young workers at the beginning of their job careers. This finding is well documented in the literature and it is consistent with implications of Sicherman-Galor model.

Gender is a statistically significant variable explaining probability of being overeducated. However, the sign of this effect depends on the definition of overeducation. For the 70-percent threshold definition, full variable models indicate that women are at higher risk of being overeducated. It turns opposite for 50-percent and lower threshold definitions, meaning that women are at lower risk of overeducation when lower thresholds are applied. Moreover, 
we observe that the lower threshold, the lower the risk of overeducation associated with being a woman. It means that women are relatively more likely to be mildly overeducated but less likely to be severely overeducated. Other studies for Poland find also that females are at lower risk of being overeducated than men (Kucel \& Vilalta-Bufi, 2012; Kiersztyn, 2013), however there is no clear link between gender and overeducation from world literature (Groot \& Maassen van den Brink, 2000).

Results for a field of study indicate that individuals who studied computer science, engineering, manufacturing and health are at lower risk of being overeducated than those who studied social sciences, business and law, which is a baseline, according to all estimations presented in Table 2. This result stands in contrast to a finding by Kucel and Vilalta-Bufi (2012) who report that studying social sciences is associated with lower risk of overeducation than studying engineering. Moreover, our analysis demonstrates that having studied services is always associated with higher than baseline risk of being overeducated. It is interesting that when we control for sector of economic activity, studying education becomes positively associated with severe overeducation (see columns 7-12). It suggests that graduates of this field, if working outside education sector, are likely to fall into severe overeducation.

Now we look at estimates for sectors of economic activity. Manufacturing is a baseline. The highest risk of overeducation is identified in case of two sectors: food services and accommodation, and trade and repairs. Those who work in trade and repairs are 2.2-2.8 times more at risk of being overeducated than those who work in manufacturing. Working in food services and accommodation is associated with 1.6-3.0 times higher risk of overeducation than working in manufacturing. Significantly lower than baseline risk of overeducation is found for education, health care, and financial services. Construction, real estate, professional and administrative activities are also associated with lower risk of overeducation.

Working part time is associated with higher risk of overeducation. Those who work part-time are 50-93\% at higher risk of overeducation than those who work full-time. Individuals who work in bigger firms, employing eleven workers or more, have lower risk of overeducation. The same applies to individuals working in public-owned firms (similar finding is found for Germany by Boll, Leppin, \& Schömann, 2016).

The effect of other worker in the household is insignificant. We added this variable to the model expecting that workers who are sole earners in their households are more likely to accept jobs that are below their education level. However, this intuition is rejected as coefficients for other worker in the household are not statistically significant in all presented estimations.

Individuals who are in households with young children, aged 3 or less, are at lower risk of being overeducated. The intuition behind this variable is that child care responsibilities make individuals less flexible in terms of working 
hours and commuting distance. Thus they are expected to face smaller number of matched job offers and be more at risk of overeducation. Estimation results suggest the opposite, though. A plausible explanation of this finding might be reversed causality: individuals who are in well-matched jobs are more likely to decide to have children.

The last two individuals' characteristics are being foreign born and being disabled. The effect of being foreign born is not statistically significant. Hence, the econometric analysis shows that immigrants working in Poland are not more at risk of overeducation than natives. This is contradictory to findings of other studies which claim that immigrants are at larger risk of overeducation (see Quintini, 2011; Aleksynska \& Tritah, 2013).

Disability is found to be associated with higher risk of overeducation. Disabled workers, even having the same other characteristics as workers without disabilities, are more are at risk of overeducation. The effect is sizeable, by 40-54\%. Only one estimation presents statistically insignificant effect of disability.

Now we move to results for degree of urbanization. It is shown in the literature that the labour market size, which can be proxied by the size of place of living, is negatively associated with the risk of overeducation (Büchel \& van Ham, 2003; Jauhiainen, 2011), as big cities usually offer better job-education match. This is also found in our analysis. All estimations show consistently that overeducation is more prevalent among workers who live in small towns and in rural areas. Living in a city of 100 thousand inhabitants or more, which is a baseline level for this variable, is associated with the lowest risk of overeducation. Overeducation risk is the highest in rural areas.

The next spatial variable included in the model is voivodship. Dolnośląskie voivodship serves as a baseline. According to all estimations, Lubelskie, Świętokrzyskie, Zachodniopomorskie are associated with significantly higher risk of overeducation than Dolnośląskie voivodship. Also Podlaskie, Warmińsko-Mazurskie and Kujawsko-Pomorskie are found to experience higher overeducation risk in majority of presented estimations. Those voivodships have in common that they are relatively less developed with still sizeable employment in agricultural sector.

The last variables included in the model are year dummies and cohort dummies. Year dummies are crucial variables to verify whether there has been rising trend of overeducation in Poland as it is suggested in the previous section. Results differ significantly when only year dummies are included, and when both year and cohort dummies are added. Firstly, we discuss the former case. The year dummies are statistically significant for higher threshold definitions. For 70-percent and 50-percent thresholds the year dummies prove that risk of overeducation is rising over time even if we control for other worker's and workplace's characteristics. However it is not proven when we analyse risk of overeducation for 40-percent and 30-percent thresholds. Altogether, it suggests 
that overeducation is rising in the middle of education-requirement distribution of occupations (mild overeducation) but there is no evidence of university graduates taking more jobs in the bottom of education requirement distribution (severe overeducation).

Lastly we report estimates for cohort dummies. Adding them into the model requires exclusion of age. It is because of that year of survey, age and year of birth are linearly dependent, hence it is impossible to have them all three in the model. Instead of reporting numbers in the table, odds ratios for cohort dummies with 95\% confidence intervals are presented graphically in Figure 3 in the appendix. We find that the risk of overeducation is associated with younger cohorts. For instance individuals born in 1980 are on average $36-62 \%$ more at risk of overeducation that workers born in 1970. When cohort dummies are used the year dummies turn decreasing over time. This is because now year dummies embrace the effect of cohort's ageing, that was previously controlled with variable age.

\section{Conclusions}

A university boom has triggered a substantial increase in a number of tertiary educated workers in Poland. It raises a question whether this surge has been properly utilised by the labour market. There is a lot of anecdotal evidence suggesting that a rising number of workers with a university diploma face obstacles to find a job that would match their education. However, there is scarcity of scientific research addressing this issue. This article contributes to filling this gap.

In the paper we analyse changes of overeducation of tertiary educated workers in Poland in 2006-2014. To identify overeducation we combine information extracted from the Balance of Human Capital survey with the Labour Force Survey. To our knowledge it is the first time that the Balance of Human Capital survey is used to analyse overeducation. The survey includes employers' declarations whether tertiary education is required for different occupations. Based on that we separate occupations into university jobs and non-university jobs and compare them with workers' actual education levels.

The results demonstrate that number of tertiary educated workers expanded by 1,890 thousand whilst university jobs expanded by between 880 thousand and 1,430 thousand, depending on definition of university jobs. Hence, the number of tertiary educated workers grew at greater pace than the number of jobs requiring tertiary education. In result the share of overeducated workers in total employment almost doubled in just eight years. The rising number of overeducated workers is driven by two factors: expansion of tertiary education and growing risk of being overeducated among tertiary educated workers. The finding of rising overeducation incidence prevails irrespective of different university job definitions. We show that overeducation is rising due to more work- 
ers taking jobs in the middle of education requirement distribution of occupations. We find less evidence of university graduates taking more jobs in the bottom of education requirement distribution. It means that rise in overeducation is driven by mild overeducation rather than severe overeducation. The econometric analysis proves the increase in a risk of mild overeducation over time. However we find that rising risk of overeducation might be alternatively explained by cohort effects.

The paper also identifies characteristics associated with overeducation. It is found that overeducated individuals are usually young with little job experience. Women are shown to be less likely in severe overeducation, whilst relatively more likely in mild overeducation. The highest risk of overeducation is identified in case of workers who work in food services, accommodation, trade and repairs. What is more, working part-time, working in small firms, working in private sector are all these factors associated with higher risk of being overeducated. The regional aspect is also important as people working in small towns or rural areas, and in less developed regions are at greater risk of overeducation.

Some fields of tertiary education are associated with low overeducation risk whilst the other with high one. The least risk of overeducation is found in case of graduates who studied computer science, engineering, manufacturing and health programmes. On the opposite, having studied services is associated with high risk of overeducation. Graduates of education studies are also at high risk of severe overeducation when working outside the education sector.

The analysis leaves an open question whether overeducation in Poland is transitory or persistent. Evidence from previous research for Poland (Kiersztyn 2011 , 2013) suggests rather persistent overeducation. Understanding factors standing behind continuous increase in overeducation incidence, which we report in the paper, would give hint about persistency of overeducation. If observed increase in overeducation is more year-specific, it is more likely to fade out with time. But if it is cohort-specific, increased risk of overeducation might be persistent over workers' life cycle. We leave this issue as an agenda for future research.

Persistency of overeducation is an important issue from the public policy perspective as it poses a risk of deterioration of human capital. De Grip, Bosma, Willems and van Boxtel (2008) find that education mismatch induces a decline in cognitive skills. Hence, persistent overeducation would require a policy response. Stimulation of demand for jobs requiring tertiary education might be such policy. Moreover, if certain skill shortages are an obstacle for overeducated individuals to take up matched jobs - as suggested by Flisi, Goglio, Meroni, Rodrigues and Vera-Toscano (2017) - the government should promote more skill-oriented training to respond shortages. Transitory overeducation would not require any specific public policy action.

The finding that a risk of overeducation significantly varies between different fields of tertiary education should attract the attention of policy makers. To 
address a high overeducation risk the government should review and update university curricula in order to ensure that universities equip graduates with skills needed by the labour market. Also it is recommended to limit number of places on university courses which are associated with the highest risk of education mismatch.

The regional differences in overeducation risk imply that there is a need to improve spatial mobility of workers within the country. Leaving less developed regions or rural areas and moving to large cities pose a chance to find a better matched job. In this context, the government should promote development of cheap rental housing in large cities. Mobility vouchers, which provide financial support to people starting a job in a different part of the country, are already available, however only to the unemployed. This instrument could be offered also to overeducated workers. Better access to job offers from all around the country provided by Public Employment Services is also recommended.

To summarise, our analysis confirms that increase in number of tertiary educated workers was associated with the rise of overeducation incidence in Poland and the pace of this change was substantial. Hence, the issue of overeducation should attract more attention of researchers and policy makers. There is a need for further research in this area. 


\section{Appendix}

Table 1. Structure of working population in Poland, 2006-2014

\begin{tabular}{|c|c|c|c|c|c|c|c|c|}
\hline & \multicolumn{4}{|c|}{ 70-percent } & \multicolumn{4}{|c|}{ 50-percent } \\
\hline & 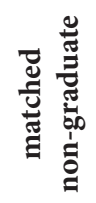 & 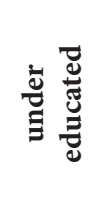 & 总 & 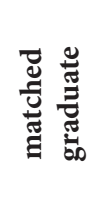 & 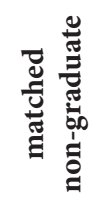 & 莺 & 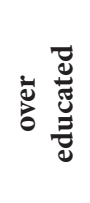 & 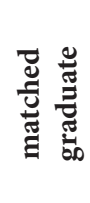 \\
\hline 2006 & $72.9 \%$ & $4.8 \%$ & $6.7 \%$ & $15.6 \%$ & $69.5 \%$ & $8.2 \%$ & $5.5 \%$ & $16.8 \%$ \\
\hline 2007 & $72.5 \%$ & $4.8 \%$ & $7.2 \%$ & $15.5 \%$ & $69.1 \%$ & $8.1 \%$ & $5.9 \%$ & $16.8 \%$ \\
\hline 2008 & $71.9 \%$ & $4.7 \%$ & $7.9 \%$ & $15.5 \%$ & $68.8 \%$ & $7.9 \%$ & $6.5 \%$ & $16.9 \%$ \\
\hline 2009 & $69.8 \%$ & $4.7 \%$ & $8.7 \%$ & $16.8 \%$ & $66.7 \%$ & $7.8 \%$ & $7.1 \%$ & $18.4 \%$ \\
\hline 2010 & $67.8 \%$ & $4.6 \%$ & $9.9 \%$ & $17.7 \%$ & $64.8 \%$ & $7.6 \%$ & $8.1 \%$ & $19.5 \%$ \\
\hline 2011 & $67.6 \%$ & $3.8 \%$ & $10.0 \%$ & $18.6 \%$ & $64.4 \%$ & $7.0 \%$ & $8.2 \%$ & $20.4 \%$ \\
\hline 2012 & $66.7 \%$ & $3.7 \%$ & $10.1 \%$ & $19.4 \%$ & $63.6 \%$ & $6.8 \%$ & $8.3 \%$ & $21.3 \%$ \\
\hline 2013 & $65.1 \%$ & $3.8 \%$ & $11.1 \%$ & $20.0 \%$ & $62.2 \%$ & $6.7 \%$ & $9.1 \%$ & $22.0 \%$ \\
\hline \multirow[t]{3}{*}{2014} & $63.8 \%$ & $3.7 \%$ & $11.9 \%$ & $20.6 \%$ & $61.0 \%$ & $6.5 \%$ & $9.8 \%$ & $22.7 \%$ \\
\hline & \multicolumn{4}{|c|}{ 40-percent } & \multicolumn{4}{|c|}{ 30-percent } \\
\hline & 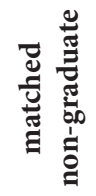 & 莺 & 总 & 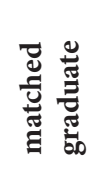 & 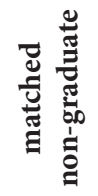 & 胥 & ¿ & 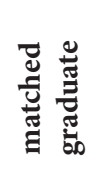 \\
\hline 2006 & $63.2 \%$ & $14.5 \%$ & $3.3 \%$ & $19.0 \%$ & $62.0 \%$ & $15.7 \%$ & $3.1 \%$ & $19.2 \%$ \\
\hline 2007 & $63.1 \%$ & $14.2 \%$ & $3.6 \%$ & $19.2 \%$ & $61.9 \%$ & $15.4 \%$ & $3.3 \%$ & $19.4 \%$ \\
\hline 2008 & $62.9 \%$ & $13.7 \%$ & $3.9 \%$ & $19.5 \%$ & $61.8 \%$ & $14.8 \%$ & $3.6 \%$ & $19.7 \%$ \\
\hline 2009 & $61.2 \%$ & $13.3 \%$ & $4.2 \%$ & $21.3 \%$ & $60.1 \%$ & $14.4 \%$ & $3.9 \%$ & $21.6 \%$ \\
\hline 2010 & $59.5 \%$ & $12.9 \%$ & $4.9 \%$ & $22.8 \%$ & $58.4 \%$ & $14.0 \%$ & $4.5 \%$ & $23.1 \%$ \\
\hline 2011 & $58.4 \%$ & $13.0 \%$ & $4.5 \%$ & $24.1 \%$ & $57.0 \%$ & $14.4 \%$ & $3.9 \%$ & $24.7 \%$ \\
\hline 2012 & $57.7 \%$ & $12.7 \%$ & $4.6 \%$ & $24.9 \%$ & $56.4 \%$ & $14.1 \%$ & $4.1 \%$ & $25.5 \%$ \\
\hline 2013 & $56.4 \%$ & $12.5 \%$ & $5.1 \%$ & $26.0 \%$ & $55.1 \%$ & $13.8 \%$ & $4.5 \%$ & $26.6 \%$ \\
\hline 2014 & $55.3 \%$ & $12.3 \%$ & $5.4 \%$ & $27.1 \%$ & $54.1 \%$ & $13.4 \%$ & $4.8 \%$ & $27.7 \%$ \\
\hline
\end{tabular}




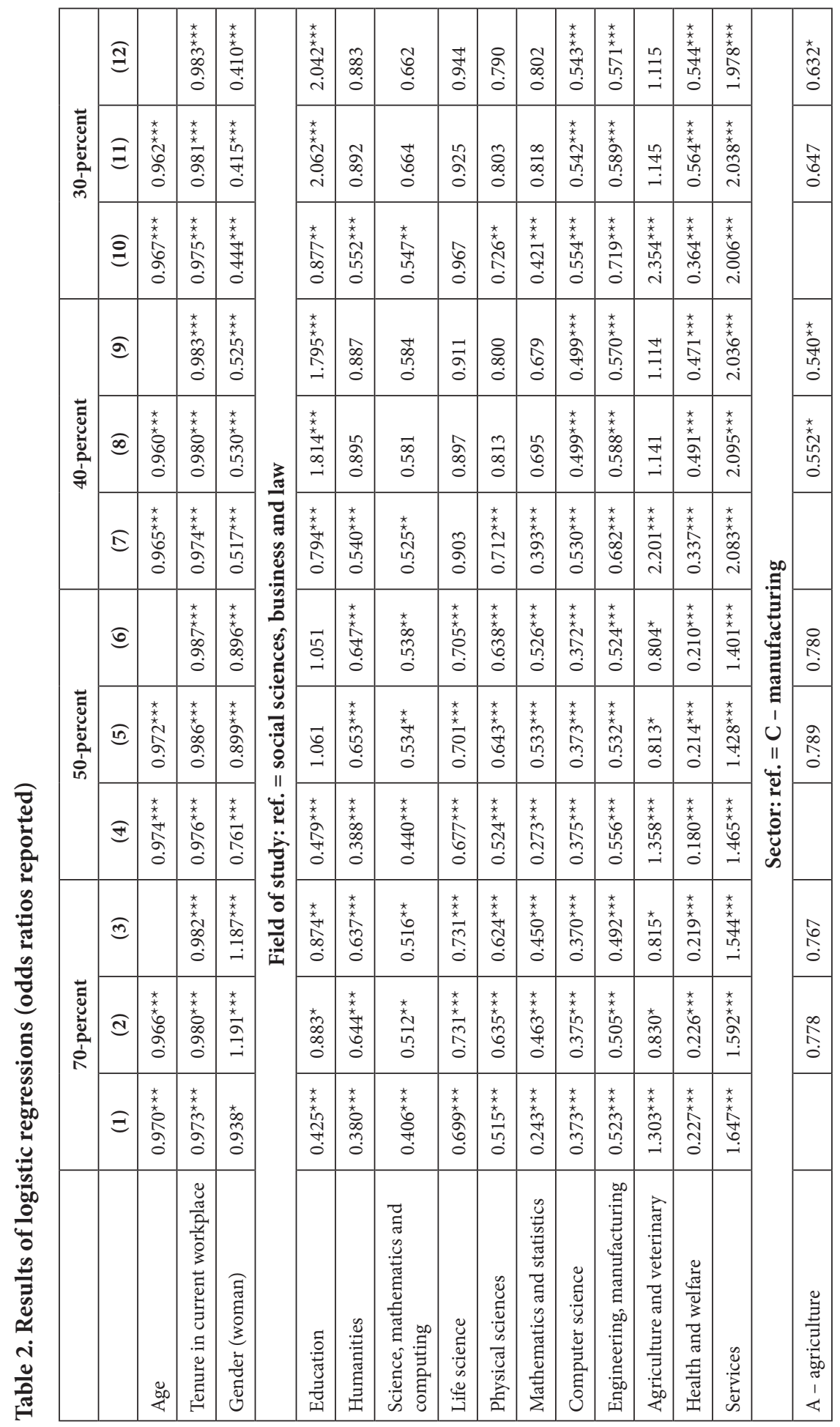




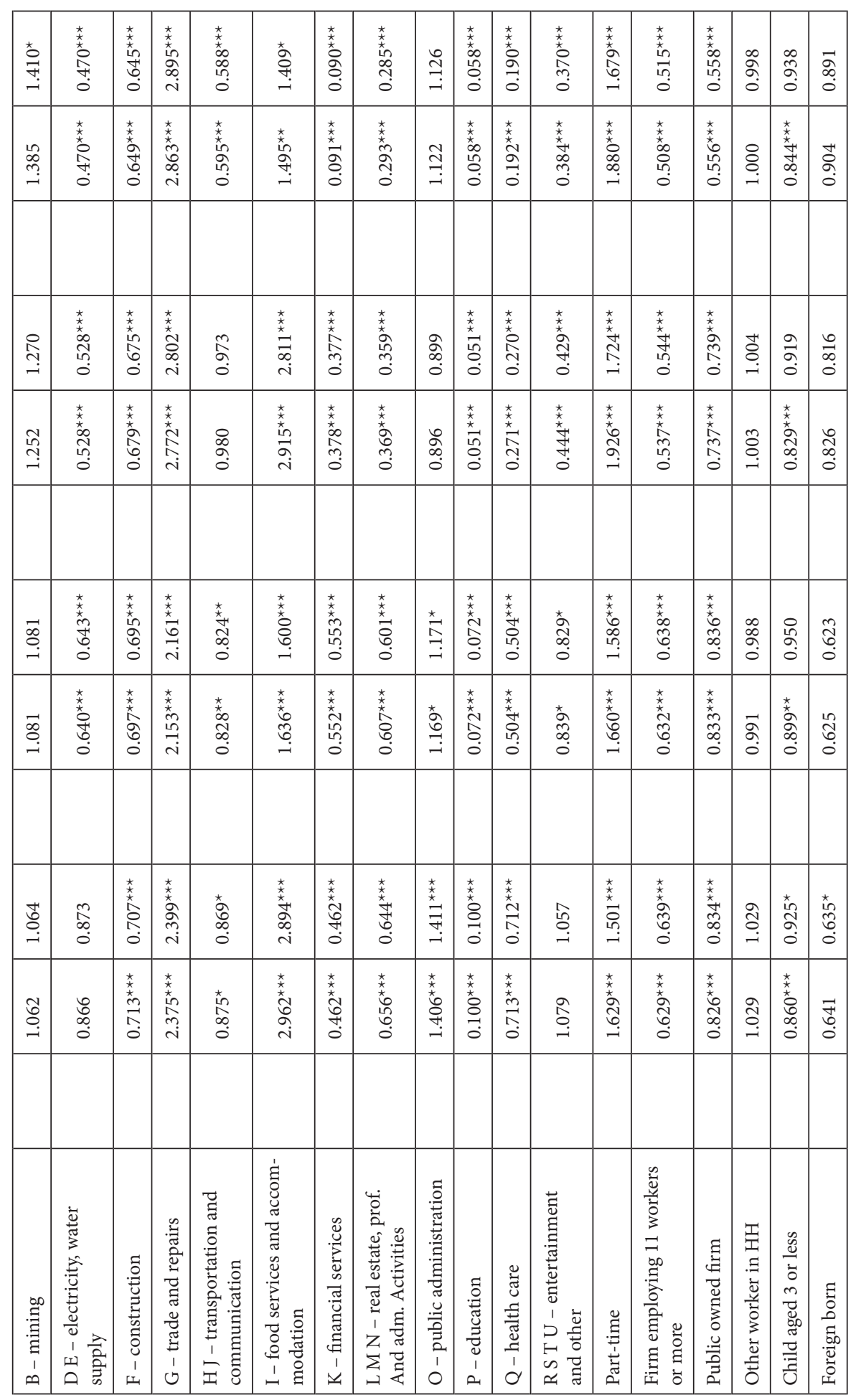




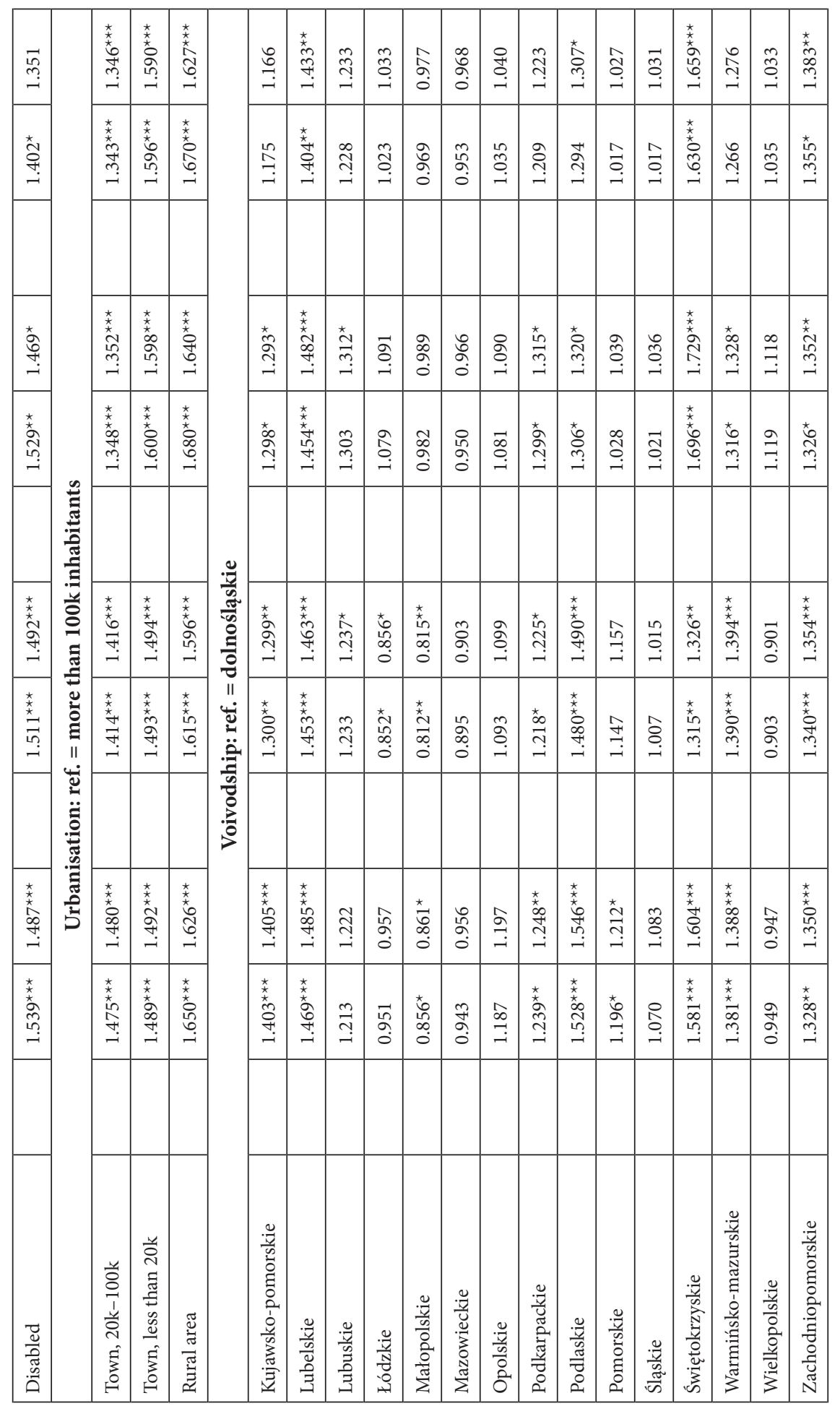




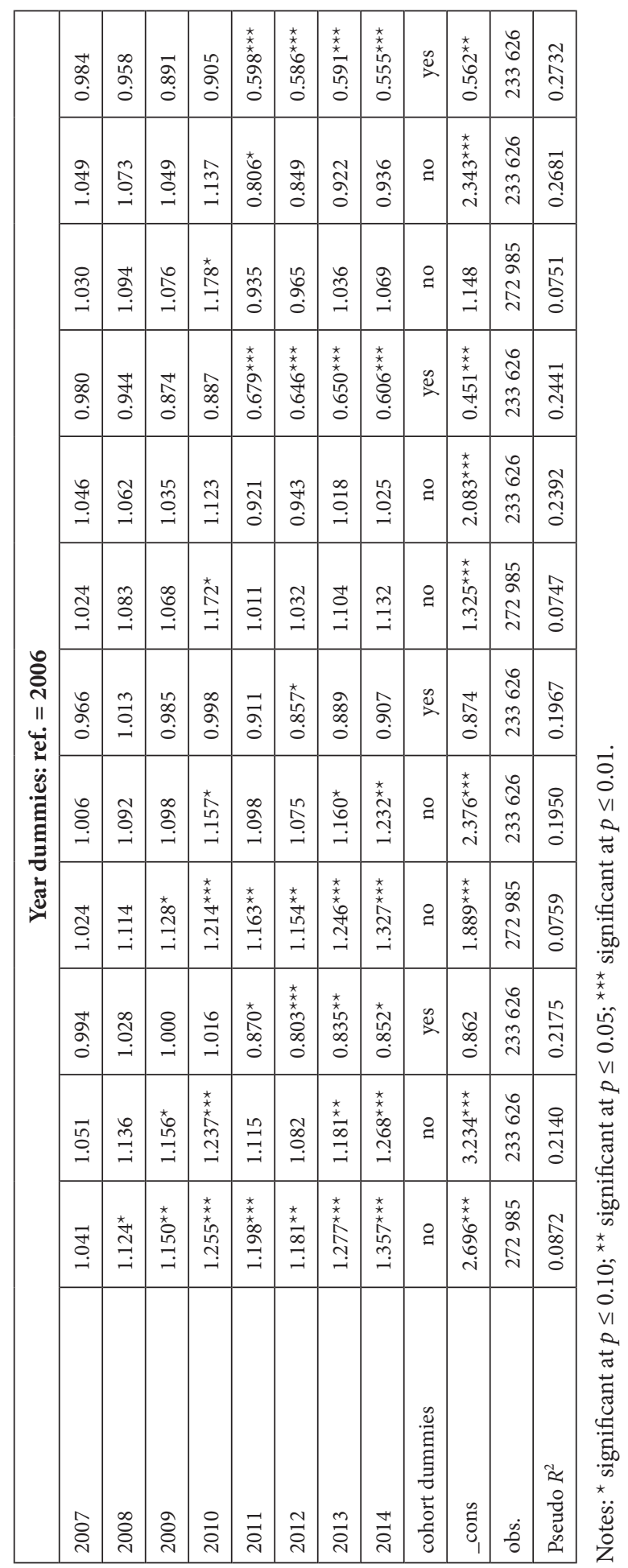


estimation (3)

70-percent university job definition

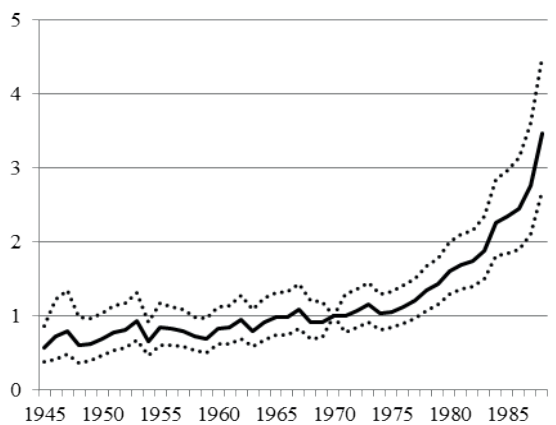

estimation (9)

40 -percent university job definition

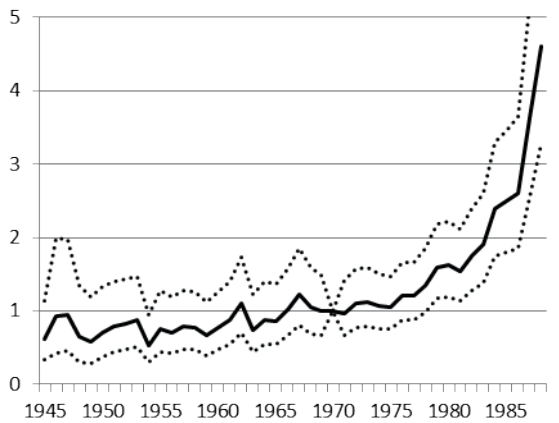

estimation (6)

50-percent university job definition

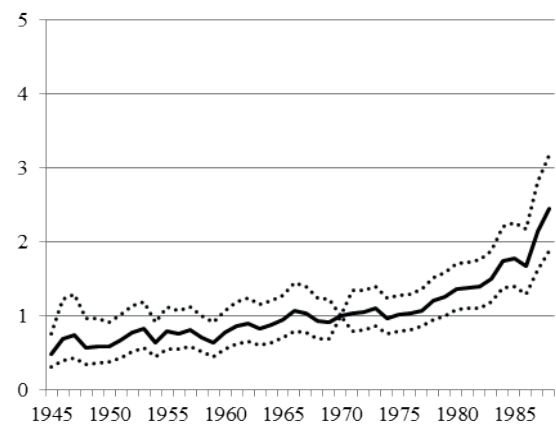

estimation (12)

30-percent university job definition

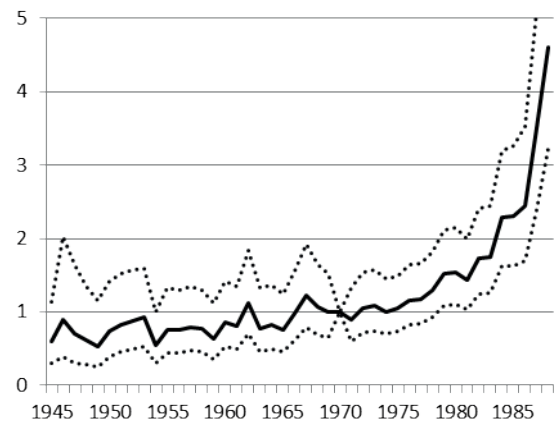

Figure 3. The odds ratios associated with cohort dummies from logistic regression presented in Table 2

Note: Odd ratios and 95-percent confidence intervals are presented. 1970 is a baseline year. 1945 is assigned to all workers born in 1945 and earlier. 1988 is assigned to all workers born in 1988 or later. 


\section{References}

Aleksynska, M., \& Tritah, A. (2013). Occupation-education mismatch of immigrant workers in Europe: Context and policies. Economics of Education Review, 36, 229-244.

Bilans Kapitału Ludzkiego (BKL). Baza badania pracodawców 2010-2014 (2015). Polska Agencja Rozwoju Przedsiębiorczości.

Boll, C., Leppin, J. S., \& Schömann, K. (2016). Who is overeducated and why? Probit and dynamic mixed multinomial logit analyses of vertical mismatch in East and West Germany. Education Economics, 24(6), 639-662.

Büchel, F., \& van Ham, M. (2003). Overeducation, regional labour markets and spatial flexibility. Journal of Urban Economics, 53, 482-493.

Chevalier, A. (2003). Measuring Over-Education. Economica, 70, 509-531.

De Grip, A., Bosma, H., Willems, D., \& van Boxtel, M. (2008). Job-worker mismatch and cognitive decline. Oxford Economic Papers, 60(2), 237-253.

Dekker, R., De Grip, A., \& Heijke, H. (2002). The effects of training and overeducation on career mobility in a segmented labour market. International Journal of Manpower, 23(2), 106-125.

Dolton, P., \& Vignoles, A. (2000). The incidence and effects of overeducation in the U.K. graduate labour market. Economics of Education Review, 19(2), 179-198.

Flisi, S., Goglio, V., Meroni, E. C., Rodrigues, M., \& Vera-Toscano, E. (2017). Measuring Occupational Mismatch: Overeducation and Overskill in Europe - Evidence from PIAAC. Social Indicators Research, 131(3), 1211-1249.

Freeman, R. B. (1976). The overeducated American. New York: Academic Press.

Frei, C., \& Sousa-Poza, A. (2012). Overeducation: permanent or transitory?. Applied Economics, 44(14), 1837-1847.

Frenette, M. (2004). The Overqualified Canadian graduate: the role of the academic program in the incidence, persistence, and economic returns to overqualification. Economics of Education Review, 23(1), 29-45.

Główny Urząd Statystyczny (2015). Badanie Aktywności Ekonomicznej Ludności 20082014 [Data file].

Gottschalk, P., \& Hansen, M. (2003). Is the proportion of college workers in noncollege jobs increasing? Journal of Labor Economics, 21(2), 449-471.

Groot, W., \& Maassen van den Brink, H. (2000). Overeducation in the labor market: a meta-analysis. Economics of Education Review, 19(2), 149-158.

Jauhiainen, S. (2011). Overeducation in the Finnish regional labour markets. Papers in Regional Science, 90(3), 573-588.

Kiersztyn, A. (2011). Racjonalne inwestycje czy złudne nadzieje: nadwyżka wykształcenia na polskim rynku pracy. Polityka Społeczna, 38(1), 7-14.

Kiersztyn, A. (2013). Stuck in a mismatch? The persistence of overeducation during twenty years of the post-communist transition in Poland. Economics of Education Review, 32(1), 78-91.

Kruger, J., \& Dunning, D. (1999). Unskilled and unaware of it: how difficulties in recognizing one's own incompetence lead to inflated self-assessments. Journal of Personality and Social Psychology, 77(6), 1121-1134.

Kucel, A., \& Vilalta-Bufi, M. (2012). Graduate labor mismatch in Poland. Polish Sociological Review, 3(179), 413-429. 
Leuven, E., \& Oosterbeek, H. (2011). Overeducation and mismatch in the labor market. In E. A. Hanushek, S. Machin, \& L. Woessmann (Eds.), Handbook of the Economics of Education (Vol. 4, pp. 282-386).

Lindley, J., \& McIntosh, S. (2010). Is the over-education wage penalty permanent? (The University of Sheffield, Department of Economics Working Paper).

Mavromaras, K., \& McGuinness, S. (2012). Overskilling dynamics and education pathways. Economics of Education Review, 31(5), 619-628.

McGuinness, S. (2006). Overeducation in the Labour Market. Journal of Economic Surveys, 20(3), 387-418.

McGuinness, S., Bergin, A., \& Whelan, A. (2015). A comparative time series analysis of overeducation in Europe: is there a common policy approach? (University of Brighton STYLE Working Papers, WP 5.1).

McGuinness, S., \& Wooden, M. (2009). Overskilling, job insecurity and career mobility. Industrial Relations: A Journal of Economy and Society, 48(2), 265-286.

Pouliakas, K. (2013). The Skill Mismatch Challenge in Europe. In Employment and Social Developments in Europe 2012. Luxembourg: Publications Office of the European Union.

Quintini, G. (2011). Over-qualified or under-skilled: a review of the existing literature (OECD Social, Employment and Migration Working Papers, No. 121).

Robst, J. (1995). Career mobility, job match, and overeducation. Eastern Economic Journal, 21(4), 539-550.

Rubb, S. (2003). Overeducation: a short or long run phenomenon for individuals?. Economics of Education Review, 22(4), 389-394.

Sicherman, N. (1991). Overeducation in the labor market. Journal of Labor Economics, 9(21), 101-121.

Sicherman, N., \& Galor, O. (1990). A theory of career mobility. Journal of Political Economy, 98(1), 169-192.

Sloane, P. J., Battu, H., \& Seaman, P. T. (1999). Overeducation, undereducation and the British labour market. Applied Economics, 31(11), 1437-1453.

Verhaest, D., \& Omey, E. (2006). The impact of overeducation and its measurement. Social Indicators Research, 77(3), 419-448.

Wasmer, E., Fredriksson, P., Lamo, A., Messina, J., \& Peri, G. (2007). The macroeconomics of education in Europe. In G. Brunello, P. Garibaldi, \& E. Wasmer (Eds.), Education and Training in Europe. Oxford: Oxford University Press. 